\title{
State-Owned Enterprise: Debts as Tools and Governmental Intervention - Evidence from China
}

\author{
Dehong Wang \\ International Business School, Beijing Foreign Studies University, Beijing, P. R. China
}

Email address:

wangdehong@bfsu.edu.cn

To cite this article:

Dehong Wang. State-Owned Enterprise: Debts as Tools and Governmental Intervention - Evidence from China. Journal of Finance and Accounting. Vol. 5, No. 4, 2017, pp. 159-164. doi: 10.11648/j.jfa.20170504.16

Received: March 10, 2017; Accepted: April 28, 2017; Published: July 6, 2017

\begin{abstract}
We examine the impacts of governmental intervention on firms' leverages ratios based on Chinese state-owned enterprises (SOEs) from 1998 to 2016. Research finds: 1) Governmental intervention is positively correlated with SOEs' leverage ratios, and this relationship is more notable when there are higher levels of governmental intervention; 2) SOEs' leverage ratios are negatively correlated with actual tax rates, and this relationship is more noteworthy for more profitable SOEs. These results also indicate: 1) In transitional countries such as China, government may serve as an important factor in firms' financing decisions. Firms can raise leverage ratios to escalate their bargaining powers with government and resist loss from governmental intervention; 2) SOEs may use debt as a tool to reduce their tax burdens in this way.
\end{abstract}

Keywords: State-Owned Enterprise, Debt Tool, Governmental Intervention

\section{Introduction}

We think that government may play an important role in firms' financing decision-making when government is an important institutional stakeholder of the firms. These firms are state-owned enterprises (SOEs). In China, local government has incentives to intervene in local SOEs to achieve political goals such as employment and GDP because the Chinese promotion system for governmental officers is strongly associated with local employment and GDP growth. There are few researches that study the relationship between firms' financing behaviors and governmental intervention. This may be due to the fact that in the western market economy governments have little impact on the micro-level behaviors of firms and governments would not intervene in firms directly. As a transitional country from planned economy to market economy, Chinese government still maintain the tradition that frequently intervenes in firms' operations including their financial activities. Bronars and Deere (1991) find that firms can utilize debt as a tool to increase their bargaining powers with labor unions, their suppliers and clients. We can think of a question like this, does debt also act as a tool for local SOEs to increases their bargaining powers to resist governmental intervention? To our best knowledge, there are few literature in this area for now.

This paper studies the relationship between the impacts of governmental intervention on the leverages ratios of local SOEs. It is based on the background of governmental intervention heterogeneity in different regions in China and the debt data of Chinese local SOEs from the year 1998 to 2016. Research shows that governmental intervention is positively correlated with the leverage ratios of local SOEs, and such relationship is more notable in the regions with higher levels of governmental intervention. The leverage ratios of local SOEs are negatively correlated with actual tax rate, and this relationship is more notable when the SOEs are more profitable. These results indicate that in transitional countries like China, government may act as an important institutional influencer in firms' financing decisions. Firms can also raise leverage ratios in order to escalate their bargaining powers with government and resist losses from governmental intervention. These results also reveal that local SOEs may take debt as a tool to reduce tax burden in this way.

The rest parts of this paper is organized as follows: in Section II we reviews the related literatures. Section III is research design. Section IV is the description of the data used in the empirical analysis in Section V. Section VI concludes this paper. 


\section{Related Literatures}

Government is an important party with interests related to firms in China. It may influence the decision-making behavior of firms. Earlier researches concentrates on the relationships between firms and financially related parties such as their shareholders and creditors. However, most researchers neglects other parties such as employees, etc. (Graham and Leary, 2011). Later, some researches alter their perspectives to firms' other parties such as their suppliers, clients and employees. There are few researches that study the relationship between firms' behaviors and governmental intervention. It may be due to the situation that in the western market economy, government usually has little impacts on the micro-level behaviors of firms and government would not intervene in firms' operations directly. However, as a transitional country from planned economy to market economy, Chinese government still retains the tradition in the planned economy that government frequently intervenes in firms' internal operations including firms' financing activities.

Wang et al (2006) thinks that the fiscal decentralization together with the political centralization is a featured characteristic of modern Chinese society. Local government officers are motivated dramatically to chase for the growth of local economy and tax revenue by the fiscal decentralization and the government officers' promotion system that are directly related to local economic growth ( $\mathrm{Li}$ and Zhou, 2005). Meanwhile, local government takes the responsibilities of commodity price stability, employment and social harmony. In most Chinese regions, local SOEs play major roles for the growth of local GDP and tax revenue as well as the reduction of unemployment. Therefore, local government has the incentives to influence local SOEs to achieve the above goals. The influence of local government on local SOEs are: 1) The actual controller of local SOEs are the local government; 2) Managers in local SOEs are usually appointed by local government, and their performance are also reviewed by local government. These provide advantageous opportunities for local governmental intervention to achieve their goals. Therefore, local government has both the incentives and the abilities to intervene in local SOEs.

Tax burden also acts as an important factor in the governmental intervention on SOEs. Compared with nonSOE firms and the SOEs controlled by Chinese central government, local SOEs usually carry heavier tax burdens (Liu and Li, 2012).

Chen et al (2011) shows that governmental intervention distorts SOEs' investment behaviors and decreases investment efficiencies. In addition, such intervention usually leads to hiring more employees than the optimal profit level (Liu et al, 2011) in order to take the responsibility of economy growth, unemployment reduction, tax revenue and social stability (Lin et al, 1998). This may cause the decreasing of firm value. On the other hand, as Chinese SOE reform goes on, firm performance indicators are becoming more and more important for the appraisal of firm managers in term of their compensation and promotions (Chen et al, 2005). In addition, the sensitivity of firm managers' compensation in SOEs to their business performance is gradually increasing (Xin and Tan, 2009). Under such situation, the decrease of firm value will damage the interests of SOE managers. In this case, local SOE managers have incentives to take actions in order to resist governmental intervention. Due to the information asymmetry between local government (the consigner) and local SOE management (the agents), local SOE managers have the abilities to resist governmental intervention.

Western researchers find that firms can utilize debt as a tool to increase their bargaining powers with labor unions and to reduce the cost of labor because labor unions as the representatives of workers will trade off between the benefits of increase on wages and the costs of bankruptcy possibilities triggered by the change of wages (Bronars and Deere, 1991). Although the benefits from wage increase for workers do not associate with firms' leverage levels, the possibility of bankruptcy is positively correlated with the amount of wage increase. When leverage ratios are higher, the unit increase of wage will trigger more possibilities of bankruptcy and hence more costs to workers.

Based on the above ideas, we come up to a similar question: does debt also act as a tool to increases the bargaining powers of local SOEs to negotiate with local government? To our best knowledge, we find few literatures covering this area up to now. Therefore, this paper focuses on the relationship between government intervention and local SOEs' leverages ratio based on the background of government intervention heterogeneity in different Chinese regions and local SOEs from 1998 to 2016. By using these data, this paper tests the relationship between the leverage ratios of local SOEs and the indices of local governmental intervention. The tests also examines: 1) Whether the more profitable local SOEs are, the stronger correlation exists between SOEs' leverage ratios and government intervention given the other conditions constant; 2) Whether the higher local SOEs' leverage ratios are, the lower the actual tax rates are imposed on these firms. It should be more notable in region with relatively higher levels of government intervention.

We think there are following contributions in this paper:

Firstly, this paper contributes to the research on the relationships between firms' operations and governmental intervention, a.k.a. the economic consequences of governmental intervention on firms' financing behaviors.

Secondly, we find: on one hand, governmental intervention affects SOEs' financing decision-making; on the other hand, SOEs' managers may use debts as a tool to resist governmental intervention. In other words, this paper reveals the relationship of government intervention and counterintervention between government and SOEs. These results provide beneficial inspirations for regulatory institutions to deal with the relationship of governments and SOEs. 


\section{Research Hypotheses and Models}

We think that the higher levels of governmental intervention in a geographical region are, the higher probability local SOE may suffer from governmental intervention. In this case, if the more SOESs raise their bargaining powers with government, the larger marginal benefit they will have. This will lead to the greater incentives for SOEs to raise their leverage ratios in the regions with higher levels of governmental intervention. Therefore, we propose Hypothesis 1: Given the other conditions constant, SOEs' leverage ratios is positively correlated with governmental intervention. The according model is:

$$
\text { Lev }_{i, t}=\alpha_{0}+\alpha_{l} \text { Government }_{i, t}+\sum \beta \text { Control }_{i, t}+\sum \gamma \text { Year }_{t}+v_{i}+\omega_{i, t}
$$

Lev $_{i, t}$ represents the leverage ratio of firm $i$ in year $t$. Government $_{i, t}$ represents the level of local governmental intervention in the region of firm $i$ in year $t$. We adopt the index of governmental intervention based on Fan (2011). According to Rajan and Zingales (1995), Flannery and Rangan(2006), we use firms' profitability (Profit), level of growth $($ Tobin $Q)$, tangible asset ratio (Tang), non-debt tax shield (NDTS), firm size (Size), median leverage ratio in the industry of the firm (Median) as controlled variables. Table 1 describes the definition of these variables. Apart from this, we use annual dummy variables to control the time effects.

Theoretically, local government has more incentives to intervene more profitable SOEs because government may get more benefits from this kind of firms. Also, the probability of bankruptcy is smaller for governmental intervention in more profitable firms. Hence, more profitable firms have higher probability of suffering from governmental intervention. Larger losses triggered by governmental intervention may lead to more incentives for firms' management to raise their leverage ratios to resist governmental intervention. Therefore, we propose Hypothesis 2: Given the other conditions constant, the more profitable local SOEs are, the stronger correlation exists between firms' leverage ratios and government intervention. In order to test Hypothesis 2, we add the interaction of profitability and level of regional governmental intervention to Model (1) and then we have Model (2).

Table 1. Variable Definitions.

\begin{tabular}{lll}
\hline Variable & Description & Annotation \\
\hline Lev & Capital structure & Lev=total liabilities/total assets \\
ATR & Actual tax rate & ATR=income tax/pretax profit \\
Profit & Profitability & Profit=EBIT/total assets \\
Size & Size of firm & Ln(ending total assets) \\
TobinQ & Level of growth & The Tobin's Q of a firm \\
Tang & Tangible asset ratio & Tang=tangible assets/total assets \\
NDTS & Non-debt tax shield & NDTS= EBITDA-EBIT/total \\
& assets \\
Median & industry & Based on the industry \\
& Level of & classification in CSRC \\
Government & governmental & The index of governmental \\
& intervention & intervention based on Fan et al \\
& & \\
\hline
\end{tabular}

${ }^{1}$ China Securities Regulatory Committee

$$
\begin{aligned}
\operatorname{Lev}_{\mathrm{i}, \mathrm{t}}= & \alpha_{0}+\alpha_{1} \text { Government }_{i, t}+\alpha_{2} \text { Government }_{i, t} \times \text { Profit }_{i, t}+ \\
& \sum \beta \text { Control }_{i, t}+\sum \gamma \text { Year }_{t}+\mathrm{v}_{\mathrm{i}}+\omega_{\mathrm{i}, \mathrm{t}}
\end{aligned}
$$

In Chinese SOEs, tax burden also serves as a major form of governmental intervention. Compared with non-SOE firms and SOEs controlled by Chinese central government, local SOEs may carry heavier tax burdens (Liu and $\mathrm{Li}, 2012$ ). If raising leverage ratio can help increase local SOEs' bargaining powers with local government, considering tax shield effect, the actual tax burden in local SOEs with higher leverage ratios will be lower, which should be more obvious in the regions with higher levels of governmental intervention. Hence, we propose Hypothesis 3: Given the other conditions constant, the higher local SOEs' leverage ratios are, the lower actual tax rates are imposed on the firms. This also should be more notable in the regions with relative higher levels of governmental intervention. The according model is Model (3).

$$
\begin{aligned}
& \operatorname{ATR}_{\mathrm{i}, \mathrm{t}}=\alpha_{0}+\alpha_{1} \operatorname{Lev}_{i, t}+\alpha_{2} \text { Government }_{i, t} \times \operatorname{Lev}_{i, t}+ \\
& \sum \beta \text { Control }_{i, t}+\sum \gamma \text { Year }_{t}+\sum \delta \text { Industry }^{+} \mathrm{v}_{\mathrm{i}}+\omega_{\mathrm{i}, \mathrm{t}}
\end{aligned}
$$

$A T R_{i, t}$ represents the actual tax rate of firm $i$ in year $t$ as the indicator of the tax burden. According to Wu (2009), Chen et al (2011) as well as Liu and $\mathrm{Li}$ (2012), we use profitability (Profit), level of growth (TobinQ), tangible asset ratio (Tang), firm size (Size) as controlled variables, which is also defined in Table 1. Similarly, we use annual dummy variables and industry dummy variables to control time effect and industry effect.

\section{Sample Description}

We use the original data of 28,426 Chinese A share market $^{2}$ firm observations from 1998 to 2016 as the sample. We have deleted: 352 observations in the financial sector; 32 with the actual controller data missing; 18,209 non-SOE observations; 1,794 central government owned SOE observations. Finally we have 7,958 effective annual data of local SOE observations, which is a panel data. The data of firms' actual controllers are from CCER database and the others are from RESSET database. When a firm's actual controller is local government or the local State-owned Assets Supervision and Administration Commission (local SASAC) ${ }^{3}$, we define the firm as a local SOE. When a firm's actual controller is Chinese central government SASAC, or other ministries of Chinese central government, or colleges and universities directly under the Ministry of Education, we define it as a central SOE (not a local SOE). The others are defined as non-SOE firms.

The descriptive statistics of the sample are shown in Table 2. For Lev: the mean is 0.4701 , median is 0.4803 , which

\footnotetext{
${ }^{2}$ A share market: the main board stock market in China

${ }^{3}$ A Chinese government agency to supervise SOEs.
} 
indicates that the overall leverage level of the firms in the sample is reasonable; Its standard deviation is 0.1802 , range from 0.0102 to 1 , which indicates that the leverage ratios vary a lot in different firms. For Government ${ }_{1}$ : average is 5.4507 with median -5.0509 . Its standard deviation is 3.0005 , range from -12.6712 to 2.1707 , which indicates that the levels of governmental intervention varies a lot in different region and in different years. For Government $t_{2}$ : average is 6.6013 and median is -6.2322 . Its standard deviation is 2.2113 with the range from minimum -11.7115 to maximum 0.0012 , which also indicates that the levels of government intervention vary a lot in different region and in different years, similar to the situation of Government $t_{1}$. For ATR: average and median are 0.1911 and 0.1611 respectively, which is lower than the nominal tax rate for the period. It is understandable considering governmental subsidy policies to SOEs. Its standard deviation is 0.1803 , from minimum 0.3002 to maximum 0.8806 , which indicates that the actual tax rates vary a lot in different SOEs. For Profit: mean and median are 0.0523 and 0.0522 , which indicates that the distribution of the profit is nearly symmetric. Its standard deviation is 0.0617 , from minimum -0.2513 to maximum 0.2209 , which indicates that the profits vary a lot in different firms.

Table 2. Descriptive Statistics.

\begin{tabular}{|c|c|c|c|c|c|c|}
\hline Variables & Sample size & Mean & StdDev & minimum & median & maximum \\
\hline Lev & 7,958 & 0.4701 & 0.1802 & 0.0102 & 0.4803 & 1.0000 \\
\hline$A T R$ & 7,958 & 0.1911 & 0.1803 & -0.3002 & 0.1611 & 0.8806 \\
\hline Government $_{1}$ & 7,958 & -5.4507 & 3.0005 & -12.6712 & -5.0509 & 2.1707 \\
\hline Government $_{2}$ & 7,958 & -6.6013 & 2.2113 & -11.7115 & -6.2322 & 0.0012 \\
\hline Profit & 7,958 & 0.0523 & 0.0617 & -0.2513 & 0.0522 & 0.2209 \\
\hline Tobin $Q$ & 7,958 & 1.4156 & 0.5455 & 0.821719 & 1.2416 & 4.3202 \\
\hline Tang & 7,958 & 0.4727 & 0.1706 & 0.0804 & 0.4705 & 0.8403 \\
\hline NDTS & 7,958 & 0.0231 & 0.0209 & 0.0027 & 0.0207 & 0.0807 \\
\hline Median & 7,958 & 0.4742 & 0.0837 & 0.2034 & 0.4629 & 0.7051 \\
\hline
\end{tabular}

Note: Based on Fan et al (2011), Government $t_{1}$ refers to the opposite number of regional marketability index; Government ${ }_{2}$ refers to the opposite number of regional decrease in government intervention. Both can stand for the government intervention level in a region.

\section{Empirical Results and Analysis}

The empirical results are shown in Table 3 and Table 4.

The results of Model (2) regression are shown in Table 3. The coefficient of Government is positively significant at $1 \%$ confidence level in both cases using Government I $_{1}$ and Government $_{2}$, which means statistically there is positive correlation between governmental intervention and firms' leverage ratios. The coefficient on the interaction of Government $\times$ Profit is also positively significant at $1 \%$ confidence level, which indicates that in more profitable SOEs, the correlation between governmental intervention and firms' leverage ratios is stronger. Therefore, these regression results verify Hypothesis 1 and 2. For the controlled variables, profit and leverage ratio Lev is negatively correlated which coincide with the theory of optimal capital structure financing order in Myers (1984). TobinQ is negatively correlated with leverage ratio Lev because of higher agent cost of debt financing for firms with higher growth rates (Myers, 1977). Another explanation is that the cost is higher when facing financial dilemma for companies with higher growth rate (Rajan and Zingales, 1995). The tangible asset ratio Tang is positively correlated with leverage ratio Lev because the value of tangible asset for mortgage is higher and hence debt financing ability is higher for firms with higher tangible asset ratio. Non-debt tax shield NDTS is negatively correlated with leverage ratio Lev because the benefit from tax shields of debts is smaller for firms with larger non-debt tax shield (DeAngelo and Masulis, 1980). The size of firms Size is positively correlated with leverage ratio Lev because on one hand the bankruptcy possibilities are smaller for bigger firms, and on the other hand there are more assets for mortgage in these firms. In conclusion, the coefficients of controlled variables coincide with our expectations from former research studies, which indicates that Model (2) is reasonable.

Table 3. Regression Results on Model (2).

\begin{tabular}{lll}
\hline Explained Variable: Lev & Government $_{\boldsymbol{1}}$ & Government $_{2}$ \\
\hline Government & $0.0038^{* * *}$ & $0.0133^{* * *}$ \\
Profit & $-0.4761^{* * *}$ & -0.0879 \\
Government $\times$ Profit & $0.0192^{* * *}$ & $0.0768^{* * *}$ \\
TobinQ & $-0.0252^{* * *}$ & $-0.0227^{* * *}$ \\
Tang & $0.1302^{* * *}$ & $0.1263^{* * *}$ \\
NDTS & $-0.7292^{* * *}$ & $-0.7033^{* * *}$ \\
Size & $0.0994^{* * *}$ & $0.1042^{* * *}$ \\
Constant & $-1.7182^{* * *}$ & $-1.7781^{* * *}$ \\
Industry Effect & Controlled & Controlled \\
Time Effect & Controlled & Controlled \\
Fixed Effect & Controlled & Controlled \\
Adj-R & 0.3821 & 0.3892 \\
F Value & $182.91^{* * *}$ & $188.62^{* * *}$ \\
Sample Size & 7,958 & 7,958 \\
\hline
\end{tabular}

Note: The first column represents the regression results using Government ${ }_{1}$ as the indicator of governmental intervention level and the second column represents that of Government . $^{* * *}$ stands for confidence level at $1 \%$, ** $5 \%$, and $* 10 \%$.

The results of Model (3) regression are shown in Table 4. 
The coefficients of $L e v$ is significantly positive at $1 \%$ confidence level. This indicates that when controlled other variable constant, the higher leverage ratio Lev is, the lower ATR firms face. The coefficient on the interaction of Lev $\times$ Government is also significantly positive at $1 \%$ confidence level. It reveals that the response of decreasing ATR to the increment in leverage ratio Lev is stronger in the region where governmental intervention level (Government ${ }_{1}$ and Government ${ }_{2}$ ) is higher. Therefore, Hypothesis 3 is checked.

Table 4. Regression Results on Model (3).

\begin{tabular}{lll}
\hline Explained Variable: ATR & Government $_{1}$ & Government $_{2}$ \\
\hline Lev & $-0.1183^{* * *}$ & $-0.1924^{* * *}$ \\
Government & 0.0041 & 0.0003 \\
Lev $\times$ Government & $-0.0137^{* *}$ & $-0.0228^{* * *}$ \\
Profit & $0.6812^{* * *}$ & $0.6761^{* * *}$ \\
TobinQ & $-0.0296^{* * *}$ & $-0.0307^{* * *}$ \\
Tang & -0.0059 & -0.0042 \\
Size & $0.03794^{* * *}$ & $0.03774^{* * *}$ \\
Constant & $-0.4983^{* *}$ & $-0.6614^{* * *}$ \\
Industry Effect & Controlled & Controlled \\
Time Effect & Controlled & Controlled \\
Fixed Effect & Controlled & Controlled \\
Adj-R & 0.0877 & 0.0896 \\
F Value & $13.8042^{* * *}$ & $14.0709^{* * *}$ \\
Sample Size & 7,958 & 7,958 \\
\hline
\end{tabular}

Note: The first column represents the regression results using Government ${ }_{1}$ as the indicator of governmental intervention level and the second column represents that of Government 2 . *** $1 \%, * * 5 \%, * 10 \%$.

We use the variable $v_{i}$ in Model (2) and Model (3) to capture unobserved factors. Time effect and industry effect are also controlled in our regressions. In addition, we use data in provincial levels as the indicator of governmental intervention. The leverage ratio level of a single firm has little impact on the overall governmental intervention level in the province. Therefore there are few possibilities of inverse casual effect. In the results of regression for Hypothesis 3, the correlation between ATR and leverage ratio Lev is negative and then we know that firms tend to raise leverage ratio as a tax shield when tax is higher indicating a positive correlation.

\section{Conclusion}

In this paper, we study the relationship between local governmental intervention and local SOEs' leverages ratios. The study is based on the background of governmental intervention heterogeneity in different Chinese regions. Our research finds the following results: 1) Local governmental intervention is positively correlated with local SOEs' leverage ratios. And this relationship is more noteworthy in the regions with higher levels of governmental intervention. 2) Local SOEs' leverage ratios are negatively correlated with actual tax rates. And such relationship is more notable for more profitable SOEs. Our results further indicates: 1) As an important interest-related institution to SOEs in China, governmental intervention does have influences on firms' financing decisions. 2) As a response, firms can raise their leverage ratios so that they can have more bargaining powers against governmental intervention and they can resist their losses from governmental intervention in this way. 3) Local SOEs may use debt as a tool to reduce their tax burdens as well.

Considering governmental intervention in SOEs and SOEs' anti-intervention, we think that SOE managers may tend to raise their leverage ratios to resist governmental intervention. Therefore, as local government, it is crucial to take firms' behaviors into consideration when conducting macroeconomic regulatory policies through governmental intervention in SOEs. SOEs' anti-intervention behaviors might cause failures for local government to achieve goals for macroeconomic policies. Local government may need consider extra measures to handle SOEs' responses.

\section{Acknowledgements}

All authors of this paper contribute equally to this work and are considered as co-first authors.

The authors thank for funding support from the Renmin University of China Science Research Foundation, Project No. 15XNI010.

\section{References}

[1] Bronars S G, D R Deere. The threat of unionization, the use of debt, and the preservation of shareholder wealth [J] The Quarterly Journal of Economics, 1991, 106(1):231 254.

[2] Chen D H, X Y Chen, H L Wan. Salary regulation and company-paid consumption in SOEs [J]. Economic Research Journal, 2005(2):92-101.

[3] Chen S, Z Sun, S Tang, D Wu. Government intervention and investment efficiency: Evidence from China [J]. Journal of Corporate Finance, 2011, 17(2):259 271.

[4] DeAngelo H, R W Masulis. Optimal capital structure under corporate and personal taxation [J]. Journal of Financial Economics, 1980, 8(1):3-29.

[5] Fan G, X L Wang, G R Ma. The contribution of marketization progress to economic growth in China [J]. Economic Research Journal, 2011(9):4-16.

[6] Flannery M J, K P Rangan. Partial adjustment toward target capital structures [J]. Journal of Financial Economics, 2006(79):469-506

[7] Graham J R, M T Leary. A review of empirical capital structure research and directions for the future [J]. Annual Review of Financial Economics, 2011, 3(1):309-345.

[8] Li H, L A Zhou. Political turnover and economic performance: the incentive role of personnel control in China [J]. Journal of Public Economics, 2005, 89(9):1743 1762.

[9] Lin J Y, F Cai, Z Li. Competition, policy burdens, and stateowned enterprise reform [J]. American Economic Review, 1998, 88(2):422 427.

[10] Liu X, X R Li. Pyramid structure, tax burden and corporate value: evidence from local state-owned enterprises [J]. Management World, 2012(8):91-105. 
[11] Liu H L, M Zhang, Y P Wang, W L Sheng. Political relationships, salary incentives and staff allocation efficiency [J]. Economic Research Journal, 2011(9):134-138.

[12] Myers S C. Determinants of corporate borrowing [J]. Journal of Financial Economics, 1977, 5(2): 147-175.

[13] Myers S C. Capital Structure Puzzle [J]. Journal of Finance, 1984, 39(3):575-92.

[14] Rajan R G, L Zingales. What Do We Know about Capital Structure? Some Evidence from International Data [J]. Journal of Finance, 1995, 50(5):1421-1460.
[15] Wang Y Q, Yan Zhang, Yuan Zhang, Z Chen, M Lu. Chinese economy in the crossroads: analysis based on current literature [J]. Journal of World Economy, 2006(10):3-20.

[16] Wu L S. State-owned equity, tax benefits and corporate tax burden [J]. Economic Research Journal, 2009(10):109-120.

[17] Xin Q Q, W Q Tan. Marketization reform, corporate performance and management compensation in SOEs [J]. Economic Research Journal, 2009(11):68-81. 